\title{
IbM JAMUR TIRAM DI DESA PENINJOAN, KECAMATAN TEMBUKU, KABUPATEN BANGLI
}

\author{
A. A. Istri Sri Wiadnyani ${ }^{1}$, I Made Sugitha ${ }^{2}$ I D.P. Kartika Pratiwi ${ }^{3}$
}

\begin{abstract}
Banjar Tampuagan merupakan salah satu Banjar yang terletak di desa Peninjoan yang berada dalam wilayah Kecamatan Tembuku, Kabupaten Bangli, sekitar $75 \mathrm{~km}$ dari Denpasar. produk pertanian yang dihasilkan di Desa Peninjoan selain padi dan palawija ada juga jamur tiram. masalah yang dihadapi adalah pada saat panen raya, dimana harga jamur tiram menjadi rendah. oleh karena itu, diperlukan suatu teknik pengolahan jmur tiram menjadi produk yang lebih variatif, tahan lama serta mempunyai nilai ekonomis yang lebih tinggi seperti: jamur crispy dan nugget jamur. Metode pemecahan masalah yang digunakan berupa pengenalan dan pelatihan pembuatan produk olahan jamur tiram, pengemasan dan manajemen pemasaran melalui kegiatan ceramah, penyuluhan pelatihan pembuatan produk olahan jamur tiram serta pendampingan selama proses produksi sampai pemasaran. Hasil yang didapatkan bahwa kegiatan penyuluhan, pelatihan serta pendampingan yang pembuatan produk produk olahan jamur tiram meliputi : pengolahan menjadi jamur crispy dan nugget jamur berjalan dengan baik. KT(Kelompok Tani) "Lancar Abadi A" dan "Lancar Abadi B" sudah mampu memproduksi produk olahan tersebut dengan baik. Pengemasan dan pelabelan pada produk pun sudah dapat dikerjakan dengan baik serta dihasilkan produk dengan identitas dan penampilan yang menarik. Selain itu, jiwa kewirausahaan meningkat dikalangan kelompok petani yang nantinya diharapkan dapat meningkatkan pendapatan dan kesejahteraan masyarakat Desa Peninjoan
\end{abstract}

Kata kunci : KT Lancar Abadi, Peninjoan, jamur tiram, jamur crispy, nugget jamur

\begin{abstract}
Tampuagan Banjar is a banjar located of Peninjoaan Village, in the district of Tembuku, Bangli regency, about $75 \mathrm{~km}$ from Denpasar. agricultural products produced in the village Peninjoan are crops such as rice and oyster mushroom. Problems encountered are during the harvest, where the price oyster mushroom is low. Therefore, required a oyster mushroom processing techniques become more varied products, durable and has a higher economic value such as: crispy mushromm and mushroom nugget. Troubleshooting methods used in the form of the introduction and training of manufacturing of processed product oyster mushroom, packaging and marketing management through lectures, training counseling manufacture of processed product oyster mushroom as well as assistance during the process of production to marketing. The results showed that the activities of counseling, training and mentoring the manufacture of processed products oyster mushroom include: processing into crispy mushroom and mushroom nugget goes well. KT (farmers) "Lancar Abadi A" and "lancar Abadi B" are able to produce the refined products properly. Packaging and labeling of the products can already be done properly and also the resulting product with an identity and an attractive
\end{abstract}

1,2,3, Jurusan Ilmu dan Teknologi Pangan, Fakultas Teknologi Pertanian Universitas Udayana. Email : asriwiadnyani@yahoo.com 
appearance as well. In addition, increasing of the entrepreneurial spirit among women KT which might be expected to increase the income and welfare of villagers Peninjoan.

Keywords: KT Lancar Abadi, Peninjoan, Oyster mushroom, crispy mushroom, mushroom nugget.

\section{PENDAHULUAN}

Kabupaten Bangli merupakan salah satu kabupaten di Provinsi Bali yang terletak disebelah Selatan Pulau Bali, sekitar $60 \mathrm{~km}$ disebelah selatan kota Denpasar. Desa Peninjoan termasuk salah satu desa yang terletak di Kecamatan Tembuku, Kabupaten Bangli. Jarak desa tersebut dari kota Denpasar adalah $\pm 75 \mathrm{~km}$ dengan waktu tempuh \pm 2 jam. Kecamatan Tembuku terdiri dari 6 desa yaitu Undisan, Peninjoan, Yangapi, Jehem, Tembuku dan Bambang. Luas wilayah Desa Peninjoan 13,5 Km2 dengan jumlah penduduk 10.135 jiwa yang terdiri dari pria 5.015 jiwa dan wanita 5.120 jiwa (Anon, 2016a). Desa Peninjoan dianggap sebagai salah satu desa terpencil dan dianggap daerah miskin sehingga banyak sekali bantuan pemerintah dalam hal pemenuhan kebutuhan pangan, sandang dan papan kepada warga miskin. Batas wilayah desa Peninjoan adalah sebelah utara desa yang api, sebelah selatan Desa Undisan, timur Desa Rendang kabupaten Karangasem dan Barat Desa Undisan (Anon, 2016b)

Mata pencaharian sebagian besar penduduk Desa Peninjoan adalah petani 2.778 orang, buruh/swasta 548 orang, pedagang 148 orang, tukang 50 orang, montir/sopir 16 orang. Luas lahan Pertanian di Desa peninjoan adalah $606 \mathrm{Ha}$ dan perkebunannya adalah $176 \mathrm{Ha}$. Salah satu hasil pertanian yang sedang berkembang di Desa Peninjoan adalah pertanian jamur tiram dan sudah terdapat kelmpok Laki Tani ( KLT) Lancar Abadi yang terdiri dari 6 orang petani jamur tiram. Letak geografis dan suhu serta lingkungan yang sesuai untuk pertumbuhan jamur di Desa Peninjoan (Anon, 2016c)

Jamur tiram (Pleurotus ostreatus) merupakan bahan makanan bernutrisi dengan kandungan protein tinggi, asam amino yang cukup lengkap, kaya akan serat, vitamin dan mineral. Mengonsumsi jamur tiram ternyata bukan hanya untuk memuaskan lidah dan mengenyangkan perut karena ternyata banyak manfaat yang berguna dari jamur. Di dalam jamur terkandung senyawa imunomodulator yakni beta-glucan yang sangat berkhasiat untuk kesehatan manusia sepert menurunkan kolesterol, anti bacteria, anti tumor (Johan, 2014)

Jamur Tiram di Desa Peninjoan, Kecamatan Tembuku, Bangli mempunyai potensi yang menjanjikan namun belum termanfaatkan secara optimal karena hanya dimanfaatkan untuk diolah menjadi cah jamur, oseng-oseng dan sup jamur, padahal jamur tiram dapat juga digunakan sebagai suatu usaha produksi di bidang pangan oleh warga untuk menambah penghasilan keluarga miskin di Desa Peninjoan. Jamur tiram sangat mudah dibudidayakan dengan produksi yang sangat tinggi. Terdapat Kelompok Tani jamur tiram di Desa Peninjoan mampu memproduksi 100 sampai 150 $\mathrm{kg} /$ hari tapi hanya menjual jamur tiram dalam bentuk segar tanpa dilakukan pengolahan lebih lanjut. Pemanfaatan jamur tiram menjadi jamur crispy dan nugget jamur dengan memanfaatkan hasil penelitian belum diketahui oleh warga desa maupun kelompok tani. Penyuluhan, pelatihan dan pengenalan proses pengolahan jamur tiram menjadi produk olahan jamur tiram diharapkan dapat meningkatkan nilai ekonomis jamur tiram dan dapat meningkatkan kesejahteraan petani jamur.

Selain memiliki potensi hasil pertanian jamur tiram yang besar, Desa Peninjoan juga merupakan daerah yang memiliki potensi pariwisata alam khususnya bukit yang sangat indah seperti : Pura Puncak sari, Pura Tirta Payuk, Bukit Pula Sari, Bukit Jati di Bunitin dan air terjun Slau di tembuku dan masih banyak lagi tempat wisata lainnya. Dengan adanya usaha pengolahan jamur tiram menjadi produk pangan maka produk-produk olahan tersebut dapat dipasarkan didaerah objek wisata tersebut sebagai produk khas oleh-oleh dari Desa 


\section{A. A. Istri Sri Wiadnyani, I Made Sugitha, I D.P. Kartika Pratiwi}

Peninjoan bagi wisatawan, sehingga dapat menjadikan Desa Peninjoan sebagai sentral pertanian jamur, industri pengolahan jamur tiram serta pariwisata yang berpengaruh di Bali.

\section{METODE PELAKSANAAN}

Pendekatan yang dilakukan untuk mencapai tujuan kegiatan ini antara lain:

1. Transfer teknologi tepat guna melalui pelatihan ketrampilan tentang pengolahan jamur tiram menjadi produk-produk olahan dengan nilai ekonomis tinggi dan dapat bertahan lebih lama seperti jamur crispy dan nugget jamur sehingga dapat meningkatkan kesejahteraan petani jamur.

2. Memberikan pelatihan tentang tata cara pengemasan produk olahan jamur tiram secara baik dan benar sehingga menghasilkan produk yang dapat memberikan nilai tambah dan memiliki daya tarik bagi pembeli.

3. Penyuluhan tentang transformasi pola pikir mitra dan pengembangan wawasan kewirausahaan kepada mitra untuk bisa mengolah jamur tiram menjadi produk yang memiliki nilai ekonomis lebih tinggi secara mandiri.

4. Melakukan pendampingan, monitoring dan evaluasi selama proses pengolahan (produksi) dan pemasaran produk olahan jamur tiram untuk mengetahui kendala-kendala yang dihadapi mitra sehingga nantinya mitra bisa berproduksi secara mandiri.

5. Memfasilitasi dan membantu proses pengurusan perijinan produk olahan jamur tirm sehingga produk yang dihasilkan benar-benar terjamin dan mendapat ijin resmi dari dinas terkait (Departemen Kesehatan, BPOM dan Departemen Perdagangan dan Perindustrian).

\section{HASIL DAN PEMBAHASAN}

\subsection{Penyuluhan dan Pelatihan Olahan Jamur Tiram}

Pelaksanaan pengabdian melalui ceramah dan pelatihan pembuatan produk olahan ubi jalar dapat memperkenalkan dan memberikan pengetahuan tambahan kepada ibu-ibu dan Bapak-bapak KT Lancar Abadi tentang teknologi tepat guna yag sederhana dalam pengolahan jamur tiram menjadi jamur crispy dan nugget jamur sehingga anggota Kelompok Tani KWT dapat menerapkannya di rumah tangga ataupun kelompoknya sekaligus mempertahankan nilai ekonomis jamur tiram disaat panen raya.

Program ini mendapat sambutan yang baik anggota Kelompok Tani. Hal ini terlihat dari tingginya antusias peserta mengajukan pertanyaan pada saat ceramah dan pelatihan baik mengenai proses pengolahannya maupun teknologi sederhana cara pembuatannya sehingga terjadi diskusi dua arah yang aktif . pengetahuan dan keterampilan peserta bertambah yang nantinya dapat dikembangkan menjadi unit usaha oleh anggota KT Lancar Abadi. Peserta penyuluhan berjumlah 20 orang yaitu KT Lancar Abadi A terdiri dari 10 orang dikoordinir oleh I Putu Karmawan dan KT Lancar Abadi B dikoordinir oleh I Made Mareada.
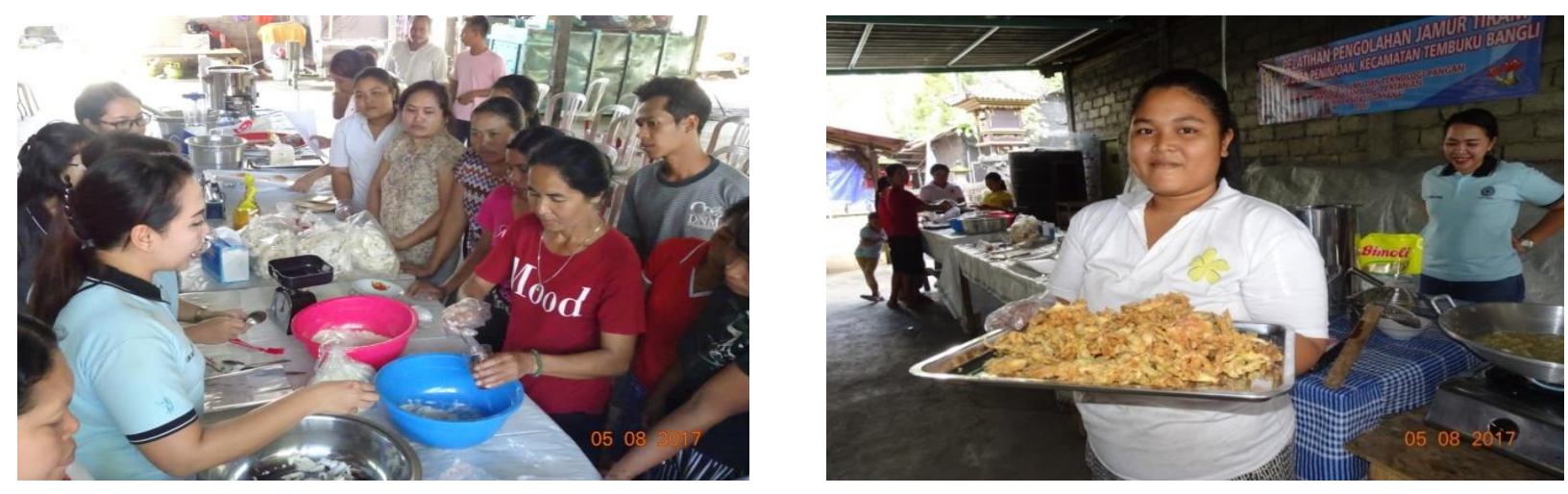

Gambar 1. Foto Pembuatan jamur crispy 

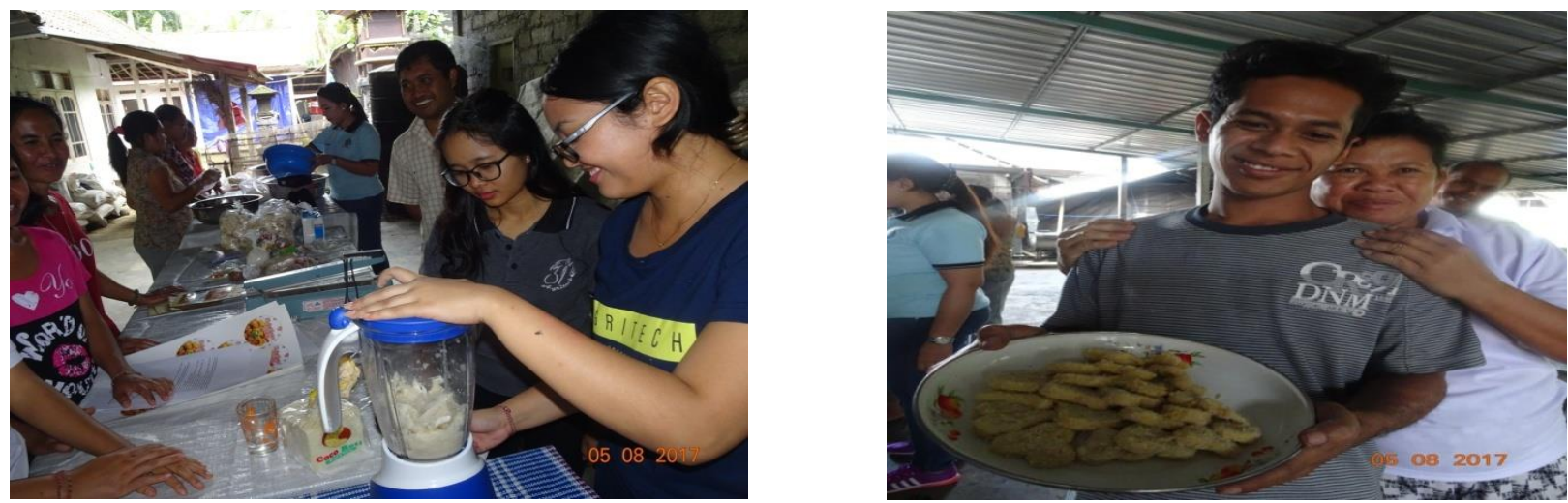

Gambar 2. Foto pembuatan nugget jamur

\subsection{Pengemasan dan Pelabelan}

Mengingat akan pentingnya fungsi dari pengemasan dan pelabelan, maka kami memberikan penyuluhan dan praktek langsung cara mengemas produk yang mereka telah hasilkan. Pemberian merek dagang tak kalah pentingnya yang memiliki 2 fungsi utama yaitu sebagai identitas bagi produk dan sebagai pembeda produk dalam bisnis yang dimiliki dengan para pesaing. Manfaat merek dalam suatu bisnis selain sebagai identitas dan membedakan dengan pesaing dapat juga untuk meningkatkan penjualan, dapat membangun loyalitas, komunikasi pasar menjadi (Wilopo, 2007).

Untuk desain label kemasan pada produk kami membantu mendesainkannya sebelumnya, dalam hal ini tetap kami komunikasikan pada saat penyuluhan untuk menerima masukan dari anggota KT. Penyuluhan dan praktek langsung pengemasan serta pelabelan produk jamur crispy dilaksanakan tanggal 27 Juli 2017 dengan merek dagang jamur crispy. Penyuluhan dan praktek langsung pengemasan serta pelabelan produk nugget jamur dilaksanakan tanggal 11 Agustus 2017 dengan merek dagang nugget jamur enak. Pengemas pada jamur crispy dalah pengemas kertas dan didalamnya dilapisi dengan aluminium foil seta ada klip bagiam atasnya (standing pot). Pengemas pada nugget adalah dari plasti Polietilen dan disiler pada bagian atasnya.
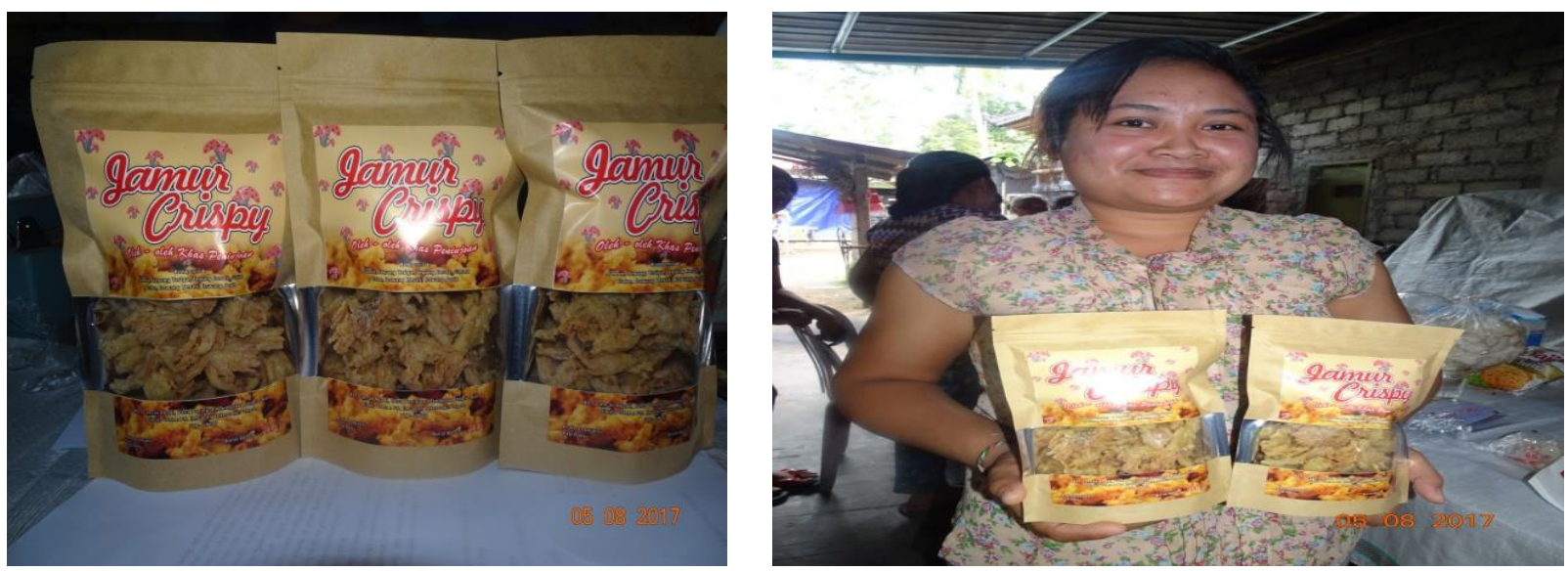

Gambar 3.Foto jamur crispy yang dikemas kertas karft dengan label 

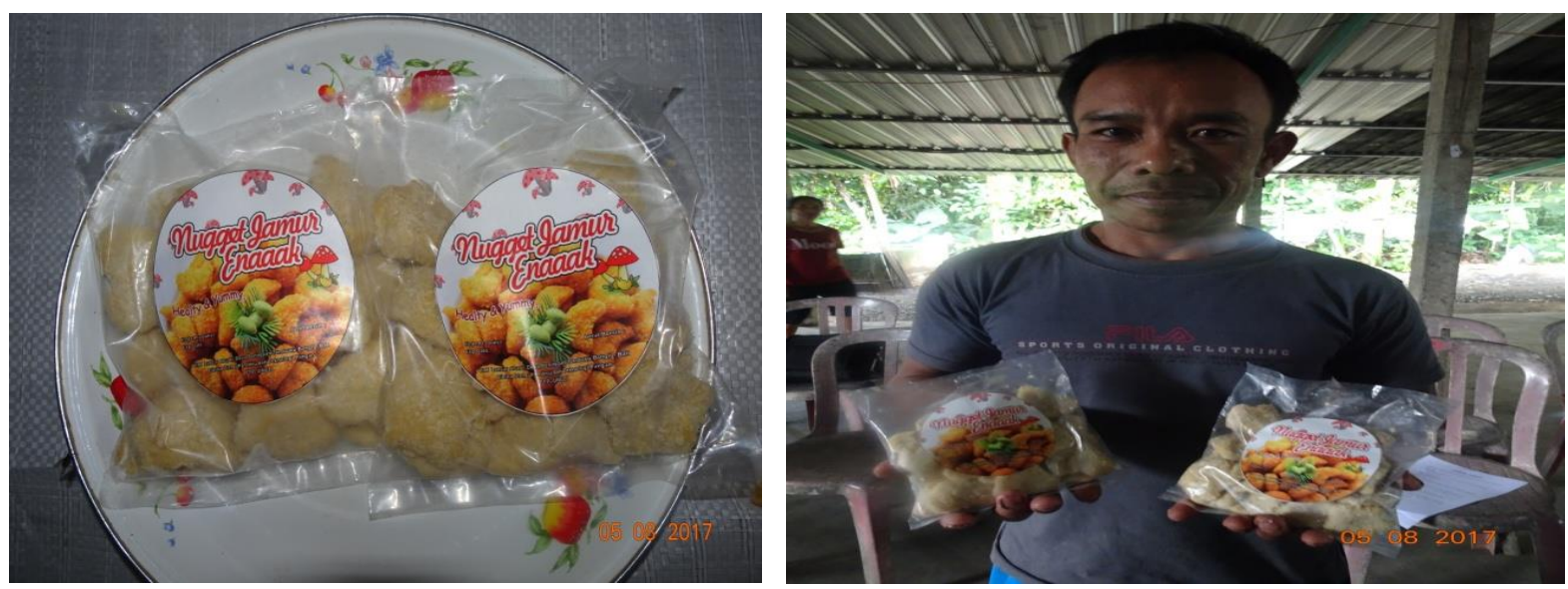

Gambar 4. Foto nugget jamur yang dikemas dengan plastik PE dengan label

\subsection{Umur Simpan Produk}

Produsen sangat perlu sekali mengetahui umur simpan produk yang diproduksinya sehingga mengetahui tanggal kadaluarsanya. Hal ini penting sekali, karena untuk mengetahui produk tersebut masih layak atau tidak untuk dikonsumsi oleh konsumen. Selama monitoring dan evaluasi yang kami lakukan maka dari beberapa produk yang diproduksi beberapa kali oleh anggota KT kami lakukan tahapan mengukur masa simpan produk olahannya tersebut. Cirri-ciri produk tersebut mulai rusak adalah pada jamur mulai melempem dan bau tengik, pada nugget rasa mulai tidak. Penentuan dari masa kadaluarsa adalah lebih pendek dari umur simpan. Untuk umur simpan adalah produk tersebut sudah rusak sedangkan masa/tanggal kadaluarsa adalah dimana produk tersebut masih layak untuk dikonsumsi. Oleh karena itu pada label perlu dicantumkan tanggal produksi dan tanggal kadaluarsanya. Masa simpan yang singkat dikarenakan produk yang dihasilkan tanpa bahan pengawet.

1. Jamur crispy kemasan kertas masa simpan \pm 35 hari maka masa kadaluarsanya 30 hari

2. nuget kemasan plastic polietilen masa simpan \pm 60 hari maka masa kadaluarsanya 50 hari

\subsection{Membangun Jiwa Kewirausahaan}

Pemberdayaan usaha mikro, kecil dan menengah (UMKM) merupakan langkah yang strategis dalam meningkatkan dan memperkuat dasar kehidupan perekonomian dari sebagian terbesar rakyat Indonesia, khususnya melalui penyediaan lapangan kerja dan mengurangi kesenjangan dan tingkat kemiskinan.

Memberikan penyuluhan berupa transformasi pola pikir Kelompok Wanita Tani untuk menjadi wirausaha yang mandiri sehingga dapat membantu perekonomian keluarga. Pemberian penyuluhan dilaksanakan tanggal 14 juli 2017 dalam rangka membuka mindset anggota Kelompok Tani untuk menjadi entrepreneur sehingga dapat membantu perekonomian keluarga (dijual di warung-warung sekitar rumah dan sekolah-sekolah ataupun dibawa ke pasar).

Selain itu pula dari kegiatan pendampingan dan pembinaan pada KT di desa Peninjoan diharapkan dapat peningkatan pengetahuan KT tentang pengolahan jamur tiram, KT dapat melakukan pengolahan sendiri sehingga nantinya dapat menjadi wirausaha mandiri dengan produktifitas yang tinggi guna meningkatkan pendapatan dan kesejahteraan masyarakat di Desa Peninjoan serta meningkatkan statusnya menjadi UKM 


\section{KESIMPULAN DA N SARAN}

\subsection{Kesimpulan}

1. Kegiatan pelatihan dapat dikatakan berhasil, karena dapat terlaksana dengan baik dan respon masyarakat yang sangat positif yang terlihat dari keaktifan peserta selama diskusi dan pelatihan berlangsung serta masing-masing kelompok sudah memproduksi secara kontinyu jamur crispy dan nugget jamur.

2. Kegiatan ini sudah terlaksana $100 \%$ sampai pada tim pengabdian menfasilitasi pengurusan ijin produk pangan industri rumah tangga (P-IRT) dari Dinas Kesehatan Kabupaten Bangli guna mencapaian tujuan untuk menaikan status KWT menjadi UKM.

\subsection{Saran}

Melihat respon masyarakat yang tinggi terhadap pelatihan Pengolahan jamur tiram menjadi jamur crispy dan nugget jamur di Desa Peninjoan, Kecamatan Tembuku, Kabupaten Bangli, maka diperlukan kegiatan serupa di daerah-daerah lain.

\section{Ucapan Terimakasih}

Ucapan terima kasih disampaikan kepada Direktorat Penelitian dan Pengabdian kepada masyarakat Direktorat Jendral Pendidikan Tinggi Kementerian Riset Teknologi dan Pendidikan Tinggi melalui Lembaga Penelitian dan Pengabdian Kepada Masyarakat Universitas Udayana atas dana yang diberikan dalam bentuk Hibah Ipteks bagi Masyarakat dengan Surat Perjanjian Penugasan Pelaksanaan Pengabdian Kepada Masyarakat Nomor: 416.13/UN.14.4.A/PM./2017 tanggal 30 Maret 2017

\section{DAFTAR PUSTAKA}

Anonimus. 2001. Teknologi Tepat Guna Agroindustri Kecil Sumatera Barat, Hasbullah, Dewan Ilmu Pengetahuan, Teknologi dan Industri Sumatera Barat.

Anonimus. 2010. Olahan Jamur Tiram. Liputan6.com, Badung.

Anonimus . 2016 a. http://www.gerbangsadumandara.provbali.info/kecamatan-tembuku-2/desapeninjoan.html. Diakses 20 Mei 2016

Anonimus.2016b.http://www.kemendagri.go.id/pages/profildaerah/kabupaten/id/51/name/bali/detail/5106/bangli. Diakses 20 Mei 2016

Anonimus. 2016c. https://id.wikipedia.org/wiki/Peninjoan,_Tembuku,_Bangli. Diakses 20 Mei 2016

Desrosier, N.W., 1988. Teknologi Pengawetan Pangan. UI-Press, Jakarta.

Julianti, E., Mimi, N. 2006. Teknologi Pengemasan. Bahan Ajar Fakultas Pertanian Universits Sumatera Utara

Johan, M. 2014. kandungan nutrisi baglog jamur tiram putih (pleurotus ostreatus) sebagai bahan pakan ternak pada masa inkubasi yang berbeda. Universitas hasanuddin, makassar 